www.jmscr.igmpublication.org

Impact Factor (SJIF): 6.379

Index Copernicus Value: 71.58

ISSN (e)-2347-176x ISSN (p) 2455-0450

crossref DOI: https://dx.doi.org/10.18535/jmscr/v6i6.160

Journal Of Medical Science And Clinical Research

IGM Publication

An official Publication of IGM Publication

\title{
Study of Mucocutaneous Involvement in HIV in a Tertiary Care Centre
}

Authors

\author{
Julie Leishangthem, Ranjeeta Sapam, Oinam Gyanpati Devi \\ J.N.I.M.S., Imphal \\ Corresponding Author \\ Ranjeeta Sapam \\ Email: ranssapam@gmail.com, Mobile: 9436891550
}

\begin{abstract}
Background: Cutaneous manifestations are common among HIV infected persons. Certain characteristic skin changes can help clinicians to recognize previously undiagnosed HIV infection.

Aims and Objectives: To determine the clinical pattern and prevalence of various mucocutaneous manifestations in HIV infected patients.

Materials and Methods: A retrospective one year study was done which included all HIV infected patients attending Dermatology OPD, J.N.I.M.S., Imphal from January 2015 to December 2015. Cutaneous findings among the patients were recorded and evaluated.

Results: The total number of patients infected with HIV attending the dermatology OPD during the study period was 146, out of which 88 (60.3\%) were males and $58(39.7 \%)$ were females. A total of 92 patients (63\%) were found to have mucocutaneous manifestations out of which 48 (52.2\%) were males and 44 (41.8\%) were females. The age group most commonly involved was 31-45 years (41.8\%). Pruritic papular eruption $(21.7 \%)$ was the most common skin involvement. The most common infections seen were candidiasis $(17.4 \%)$, dermatophytosis $(7.6 \%)$, herpes zoster $(5.4 \%)$, human papilloma virus infection (3.3\%), herpes simplex virus infection (3.3\%), folliculitis (3.3\%) and chancroid (3.3\%). Seborrheic dermatitis (6.5\%), maculopapular drug rash (4.3\%), generalized pruritus (3.3\%)were common noninfectious conditions seen. Penicilliosis (5.4\%) was also seen.

Conclusion: Mucocutaneous involvement occurs in every stage of HIV and awareness of the varied pattern of these manifestations would help in the early diagnosis and management of HIV infection, thereby decreasing the morbidity and improve the quality of life in them.
\end{abstract}

\section{Introduction}

Skin and mucocutaneous diseases can be seen in every stage of human immunodeficiency virus (HIV) infection, including asymptomatic stages ${ }^{1}$. Previous studies have found that approximately $90 \%$ of HIV-infected patients have skin lesions ${ }^{2,3}$ and that these are often the first indication that the patient is infected with HIV. The mechanism by which HIV-infected patients are prone to skin disease appears to be correlated with the degree of immunodeficiency ${ }^{4}$. Many skin diseases may in fact be considered valuable and sensitive indicators for the diagnosis of HIV and for monitoring disease progression and treatment efficacy ${ }^{5,6}$.

The hallmark of HIV infection is a progressive, qualitative and quantitative deficiency of helper CD4 T lymphocyte which is needed for foreign antigen presentation and phagocytosis. When the number of CD4 cells declines below a certain 
level, opportunistic conditions including unusual infections and neoplasms set in. With the advent of antiretroviral therapy (ART), many of the skin disorders associated with HIV disease (e.g. Kaposi sarcoma) as well as serious opportunistic infections are observed less frequently than in the past $^{7}$.

\section{Materials and Methods}

A retrospective one year study was done which included all patients with HIV infection attending Dermatology OPD, J.N.I.M.S., Imphal from January 2015 to December 2015. All the patients underwent complete dermatological examination. Mucocutaneous diseases were diagnosed by experienced dermatologists. The clinical diagnosis was confirmed by laboratory tests like $\mathrm{KOH}$ examination, Tzanck smear, culture histopathological examination, etc. whenever necessary.

\section{Results}

Out of 146 patients infected with HIV, 88 (60.3\%) were males and $58(39.7 \%)$ were females. 92 $(63 \%)$ were found to have mucocutaneous manifestations. Out of these 92 patients, 48 $(52.2 \%)$ were males and $44(41.8 \%)$ were females. Table 1 shows gender-wise distribution of cases. Majority of patients were within the age group 3145 years $(41.8 \%)$ followed by $16-30$ years (21.9\%) and 46-60 years (19.9\%). Table 2 shows frequency of distribution of cases according to the age group.

The most common skin involvement seen was pruritic papular eruptions which was seen in 20 (21.7\%) patients. Among the infective conditions, candidiasis was the most common and was seen in $16(17.4 \%)$ patients followed by dermatophytosis (7.6\%). Other fungal infection seen was onychomycosis (2.2\%). Among the viral infections, the most common were herpes zoster (5.4\%), human papilloma virus infection (3.3\%) and herpes simplex virus infection (3.3\%).3 patients $(3.3 \%)$ presented with molluscumcontagiosum . 4 patients presented with bacterial infections like folliculitis (3.3\%) and impetigo
(1.1\%). Norwegian scabies was seen in 1 patient. Sexually transmitted infections (STIs) like chancroid $(3.3 \%)$ and primary chancre $(1.1 \%)$ were also seen. 7 patients $(5.4 \%)$ presented with penicilliosis. Other than pruritic papulareruptions, non-infectious conditions like seborrheic dermatitis (6.5\%), maculopapulardrug rash $(4.3 \%)$, generalized pruritus (3.3\%), Steven Johnson Syndrome (1.1\%), pigmentary disorders $(1.1 \%)$ and ichthyosiform dermatitis $(1.1 \%)$ were also seen.

Table 1 Gender wise distribution of cases

\begin{tabular}{|l|c|c|}
\hline Gender & Number of Patients & Percentage (\%) \\
\hline Male & 88 & $60.3 \%$ \\
\hline Female & 58 & $39.7 \%$ \\
\hline
\end{tabular}

Table 2 Age-wise distribution of cases

\begin{tabular}{|l|c|c|}
\hline Age & Number of Patients & Percentage (\%) \\
\hline$<=15$ Years & 10 & $6.8 \%$ \\
\hline $16-30$ Years & 32 & $21.9 \%$ \\
\hline $31-45$ Years & 61 & $41.8 \%$ \\
\hline $46-60$ Years & 29 & $19.9 \%$ \\
\hline$>60$ Years & 14 & $9.6 \%$ \\
\hline
\end{tabular}

Table 3 Frequency of different types of mucocutaneous diseases

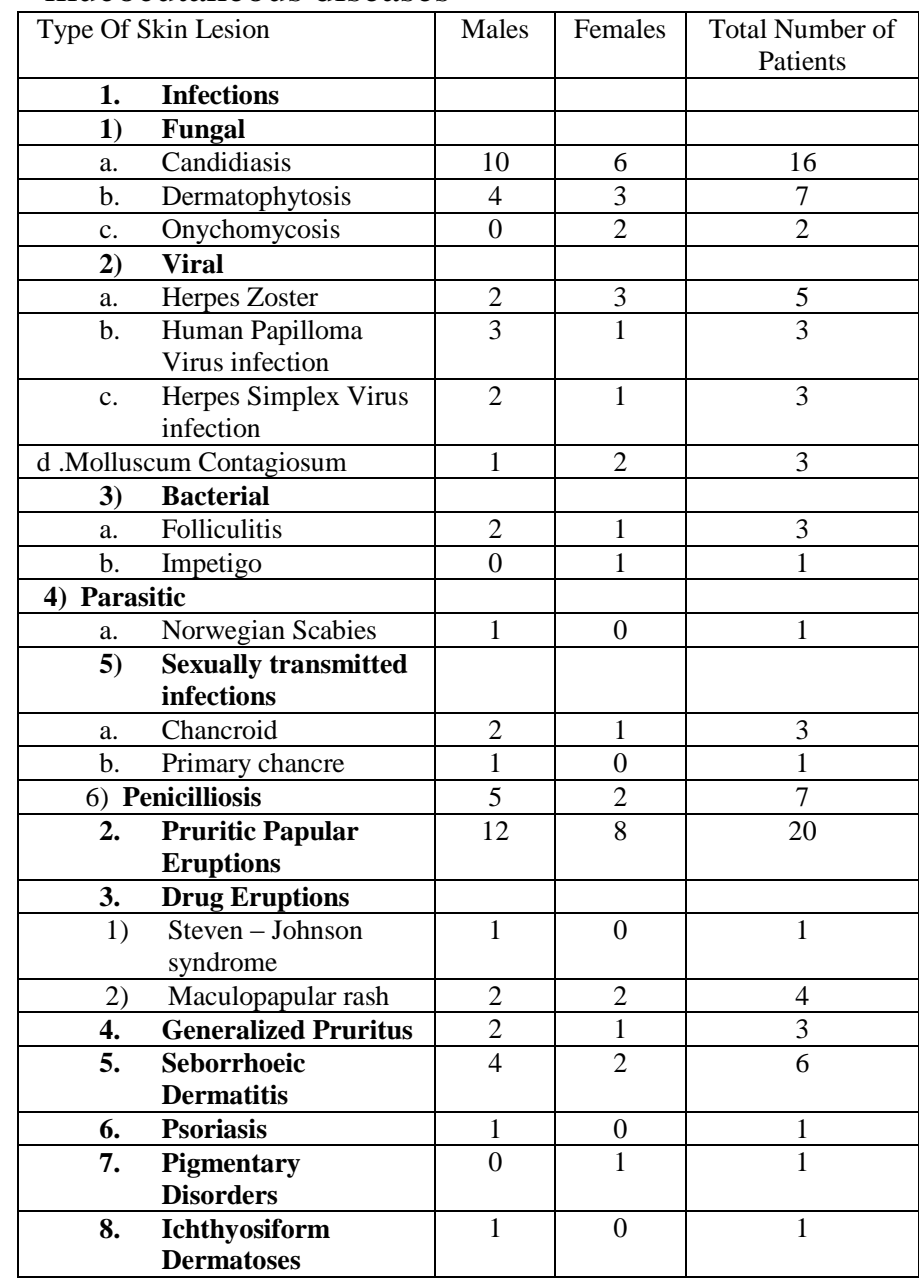




\section{Discussion}

Skin disorders are frequent among persons infected with $\mathrm{HIV}^{8}$. In many cases, the presence of a skin disorder is the first manifestation of HIV infection $^{9}$ and serves as an early indicator of clinical T-cell deficiency ${ }^{10}$. The frequent findings of cutaneous disorders in HIV infected individuals is due to the fact that the skin itself is an immune system containing antigen presenting (Langerhan) cells. There is evidence thatthe numbers of Langerhan cells are decreased in AIDS because they are also targets of HIV infection ${ }^{11}$.

Previous studies show that dermatological manifestations are seen at every stage of HIV/ AIDS and are often the presenting feature ${ }^{1}$. These manifestations not only act as disease markers, but also reflect the underlying immune status ${ }^{5}$.

In the study population male patients outnumbered female patients. Males comprised $60.3 \%$ of cases which is also nearly similar to $59.5 \%$ reflected from the national statistics of HIV population ${ }^{12}$. Male predominance was also observed in studies done by Joge US et $\mathrm{al}^{13}, \mathrm{Z}$. Ahmad ${ }^{14}$ et al and Nayak et $\mathrm{al}^{15}$. This could be due to the fact that in the existing social milieu, females do not seek medical care fearing social stigma and gender bias and females acquire HIV mainly through spouses except for few.

Majority of patients were within the age-group 1645 years which is sexually active and productive age group. These findings are very much similar to the national level statistics in NACO which has reported that $89 \%$ of cases were in the age group $15-44$ years $^{16}$.

In our study, $63 \%$ of the HIV infected patients presented with mucocutaneous involvement which falls somewhere between the incidence observed by Wiwanitkit $(80 \%)^{17}$ and Shobana et al $(40 \%)^{18}$. This finding is also consistent with other studies, including studied by Mythili Chandrasekaran et al $(51 \%)^{19}$ and T.Y. Tzung et al $(70 \%)^{20}$.

The most common skin disorder seen was pruritic papular eruption (13.7\%). This is consistent with the study by Kullavanijaya et $\mathrm{al}^{21}$. PPE remains the most common cutaneous manifestation in HIV disease, with prevalence varying between $11 \%$ and $46 \%$ according to the geographic area; and it is more prevalent in less developed countries of the world ${ }^{22}$.

Among the infective dermatoses, the most prevalent was oral candidiasis (17.4\%). Dermatophytosis (7.6\%) was another common fungal infection seen. In our study, herpes zoster (5.4\%) was the most common viral infection seen. This is similar to other reports but differed from the study of Goldstein et al $(1997)^{23}$. The other common infectious conditions seen were human papilloma virus infection (4.3\%), herpes simplex virus infection (3.3\%) and folliculitis (3.3\%). This is similar to studies by Supanarano-ndetal ${ }^{24}$ and Murugan Swamiappan et $\mathrm{al}^{25}$.

In our study, 7 patients $(7.6 \%)$ presented with cutaneous penicilliosis, which were confirmed with biopsy and culture. Sivayathorn et al, in their study on the prevalence of skin disease in HIVinfected patients in Bangkok found that 3.2\% of their study subjects were diagnosed as having cutaneous penicillium marneffei infection ${ }^{26}$. Shobhana et al, in their study conducted in Calcutta, on mucocutaneous manifestations of HIV/AIDS did not detect a single case of penicillium marneffei infection among their study subjects $^{18}$. Findings with regard to penicillium marneffei in the present study are more similar with reports from other studies in Southeast Asia than those in India ${ }^{27}$.

No cases of oral hairy leukoplakia (OHL) were reported in our study. This is similar to the study of Kullavanijaya and Bisalbutra (1997) which reported a low incidence of oral hairy leukoplakia ${ }^{21}$ but differed from the study by Chiewchannvit and Wongmaneeroin (1993) where OHL was a common finding ${ }^{28}$.

There were a striking low number of sexually transmitted diseases detected in our study population. This could be due to various reasons like the active intervention of nongovernmental organizations which have set up special HIV and STD clinics in the city ${ }^{7}$. 
Among the non-infective conditions, pruritic papular dermatoses was the most common followed by seborrheic dermatitis (6.5\%), maculopapular drug rash $(4.3 \%)$ and generalized pruritus $(3.3 \%)$. Seborrheic dermatitis was found to be a common non-infectious dermatoses in studies done by Munoz-Perez MA et $\mathrm{al}^{29}$, Singh $\mathrm{H}$ et $\mathrm{al}^{30}$ and Sharma YK et $\mathrm{al}^{31}$.

\section{Conclusion}

A broad spectrum of HIV- associated skin changes were observed in our study. Awareness of the varied pattern of these manifestations can help in early diagnosis and management of HIV. The prevalence of various disorders may however vary depending on the geographical locaton. In region like ours, rare endemic infections like penicilliosis should be considered.

\section{References}

1. Valle SL, Saxinger C, Ranki A, Antonen J, Suni J, Lähdevirta $J$, et al. Diversity of clinical spectrum of HTLV-III infection. Lancet 1985; 1: 301-304.

2. Kumarswamy N, Sunti S, Madhivanan P, Ravikumar B, 2. Thyagarajan SP, Yesudian P. Dermatologic manifestations among immunodeficiency virus patients in South India. Int J Dermatol 2000; 39: 192-195.

3. Tzung TY, Yang CY, Chao SC, Lee JY. Cutaneous mani-3. festations of human immunodeficiency virus infection in Taiwan. Kaohsiung J Med Sci 2004; 20: 216-224.

4. Muñoz-Pérez MA, Rodriguez-Pichardo A, Camacho F, 4. Colmenero MA. Dermatological findings correlated with CD4 lymphocyte counts in a prospective 3 year study of 1161 patients with human immunodeficiency virus disease predominantly acquired through intravenous drug abuse. Br J Dermatol 1998; 139: 33-39.

5. Raju PV, Rao GR, Ramani TV, Vandana S. Skin disease: clini-14. cal indicator of immune status in human immunodeficiency virus (HIV) infection. Int J Dermatol 2005; 44: 646-649.

6. Nnoruka EN, Chukwuka JC, Anisuiba B. Correlation of mucocutaneous manifestations of HIV/AIDS infection with CD4 counts and disease progression. Int $\mathbf{J}$ Dermatol 2007; 46 Suppl 2: 14-18.

7. Sailo L et al. Int J Res Dermatol. 2017 Dec;3(4):506-511

8. Siriyathorn A, Srihra B, Leesanguankul W. Prevalence of skin diseases in patients infected with human immunodeficiency virus in Bangkok, Thailand. Ann Acad Med Singapore 1995; 24: 529-33.

9. Calabrese L, Proffitt MR, Levin KH. YenLieberman B, Starkey C. Acute infection with the humanimmunodeficiency virus (HIV) associated with brachial neuritis and xanthematous rash. Ann Intern Med 1987; 107: 849-51.

10. Johnson RA, Dover JS. Cutaneous manifestation of human immunodeficiency virus disease. In : Fitizpatrick TB, Eisen AZ, Wolff K, Freedberg IM, Austin KF, eds. Dermatology in General Medicine. 4th ed. New York: Mc Graw-Hill, 1993: 263789

11. Tschachler E, Bergstresser PR, Stingl G. HIV-related skin disease. Lancet 1996; 348: 659-93

12. Annual report: NACO; 2014-15. HIV estimation. 2015

13. Joge US, Deo DS, Lakde RN, Choudhari SG, Malkar VR and Ughade HH. Socio demographic and clinical profile of HIV/AIDS patients visiting to ART Centre at a rural tertiary care hospital in Maharashtra state of India. Int J Biol Med Res. 2012;3(2):1568-72

14. Zaheer MS, Rabbani MU, Zuber Ahmed, Tamkin Khan, Rewari BB, Pandey DK. Clinical and demographic profile of patients of AIDS in and around Aligarh. JIACM. 2003; 4(2):121-26 
15. Nayak UB, Lenka S. Clinical and Socio demographic profile of attendees at ART centre in a tertiary care hospital in Mangalore, India. Asian Journal of Medical Sciences. 2015;6:5.

16. HIV and AIDS statistics commentary. UNAIDS/ WHO AIDS epidemic update, November 2007. Available at http://www.org

17. Wiwanitkit V. Prevalence of dermatological disorders in Thai HIV-infected patients correlated with different CD4 lymphocyte count statuses: A note on 120 cases. Int J Dermatol. 2004;43:265-

18. Shobhana A, Guha SK, Neogi DK. Mucocutaneous manifestations of HIV infection. Indian $\mathbf{J}$ Dermatol Venereol Leprol. 2004;70:82-6

19. Dr. Mythili Chandrasekaran. " Dermatological Manifestations of Hiv - Study of 100 Cases." IOSR Journal of Dental and Medical Sciences (IOSR-JDMS) 16.8 (2017): 22-25

20. Tzung TY, Yang CY, Chao SC, Lee JY. Cutaneous manifestations of human immunodeficiency virus infection in Taiwan. Kaohsiung J Med Sci 2004; 20: 216-224

21. Kullavanijaya P, Bisalbutra P. Frequency distribution of skin diseases in HIV infected patients (1991-1995) Institute of Dermatology, MOPH, Bangkok, Thailand. Dematology 2000. Bangkok: Holistic Publishing. 1997: 513

22. Lakshmi S J, Rao G R, Ramalakshmi, Satyasree, Rao K A, Prasad P G, Kumar Y H. Pruritic papular eruptions of HIV: A clinicopathologic and therapeutic study. Indian J DermatolVenereolLeprol [serial online] 2008 [cited 2018 Jun 11];74:501-3

23. Goldstein B, Berman B, Sukenik E, Frankel SJ. Correlation of skin disorder with CD4 lymphocyte counts in patients with
HIV/AIDS. J Am AcadDermatol 1997; 36: 262-4

24. W. Supanaranond, V. Desakorn, C. Sitakalin, N.Ngaing, P.Chirachankul. Cutaneous manifestations in HIV positive patients.Southeast Asian J Trop Med Public Health 2001 Mar;32(1):171-6

25. Swamiappan M, Chandran V, Ramasamy S, et al. Pattern of mucocutaneous manifestations of HIV infected patients: a retrospective study. J. Evolution Med. Dent. Sci. 2016;5(59):4060-4063

26. Sivayathorn A, Sriha B, Leesanguankul W. The spectrum of mucocutaneous manifestations during the evolutionary phases of HIV diseases: an emerging Indian scenario. J Dermatol. 1999;26 (5):194-302

27. Nissapatorn V. Lessons Learned About Opportunistic Infections in Southeast Asia. Southeast Asian J Trop Med Public Health. 2008;39:625-41

28. Chiewchannvit S, Wongmaneerojn $T$. Prevalence of cutaneous disease in HIVinfected patients at MaharajNakhon Chiang Mai Hospital, Thai J Dermatol 1993; 3: 20513

29. Munoz-Perez MA, Rodriguez-Pichardo A, Camacho F, et al. Dermatological findings correlated with CD4 lymphocyte counts in a prospective 3 year study of 1161 patients with human immunodeficiency virus disease predominantly acquired through intravenous drug abuse. Br J Dermatol 1998;139(1):33-9

30. Singh H, Singh P, Tiwari $P$, et al. Dermatological manifestations in HIVinfected patients at a tertiary care hospital in a tribal (Bastar) region of Chhattisgarh, India. Indian J Dermatol 2009;54(4):338-41

31. Sharma YK, Sawhney MPS, Bhakuni DS, et al. Orocutaneous manifestations as markers of disease progression in HIV infection in Indian setting. MJAFI 2004;60(3):239-43. 